Historic, archived document

Do not assume content reflects current scientific knowledge, policies, or practices. 


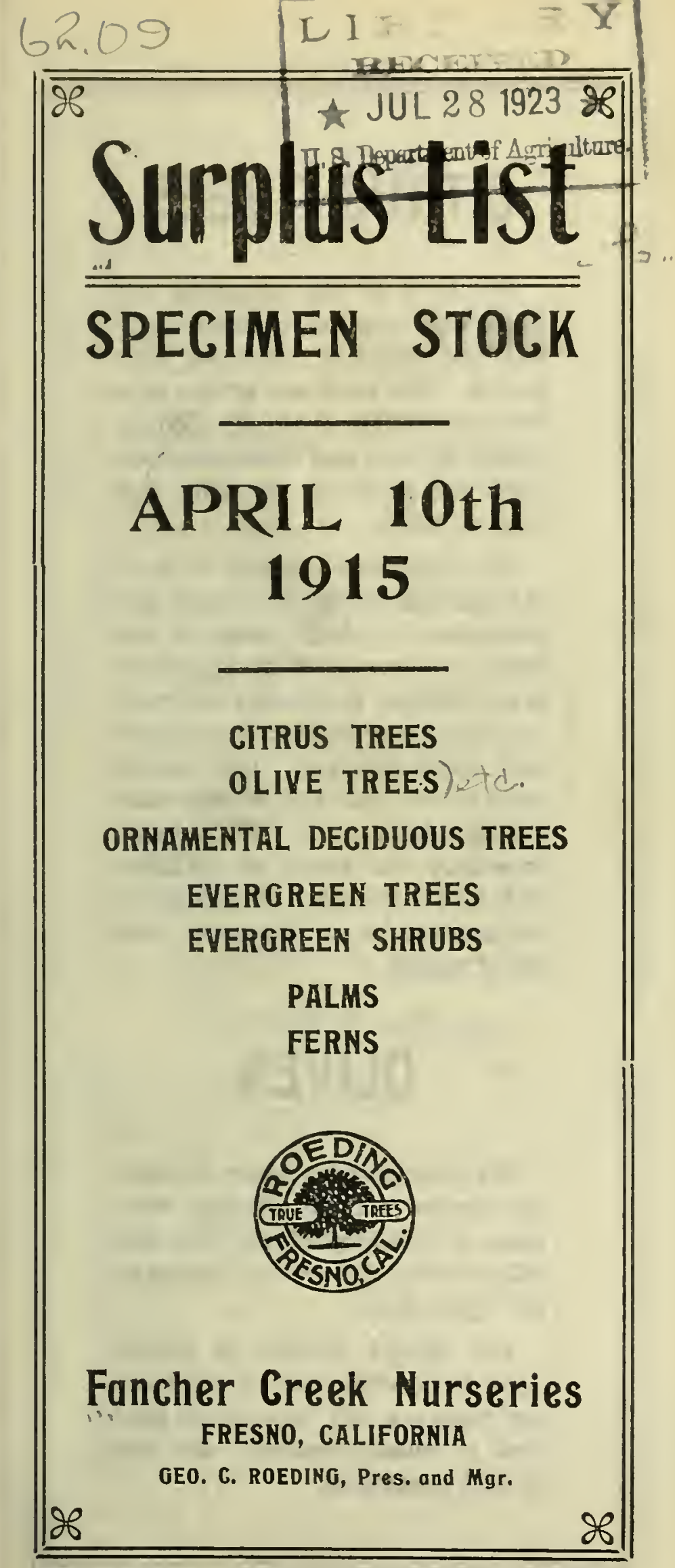




\section{CITRUS TREES}

We have in our nurseries the finest assortment of Oranges, Lemons and Pomelos we have ever grown. Our trees are grown in a favored location in Orange County where the soil and climatic conditions are ideal for growing this class of stock.

Our customers to whom we have shipped this stock this season are unanimous in their praise of our stock, on account of its fine, dark green foliage, uniformity of grading, and being in first class condition when received. Our assortment is complete and we are making attractive prices. We have an especially fine block of VALENCIA IATE Oranges. If you are in the market let us figure on your list of wants.

\section{OLIVES}

We anticipated a heavy demand this season for the leading varieties of pickling olives.. We can still furnish them in all grades at low quotations.

You should arrange to border your place with these profit bearing trees,-a big income on land that is usually wasted. Get our special quotations. 


\section{Ornamental Deciduous Trees}

The following list eomprises the best speeimen trees we have now heeled in on our paeking yards ready for immediate delivery. They are in fine condition and can be paeked and shipped with perfeet safety. The quotations are diseonnted to move this stock. Iet us have your order. It is advisable to act promptly. You can wire us your order-our expense.

\begin{tabular}{|c|c|c|c|c|}
\hline & ety & Size & & \\
\hline 50 & Catalpa, & to 12 & & .50 \\
\hline 85 & Catalpa, Western ................... & & & .40 \\
\hline 45 & Catalpa, Western .................. & & & .30 \\
\hline 5 & Eln, American White........ & & & .40 \\
\hline 20 & Elm, Anıerican White........ & to 8 & & .30 \\
\hline & Elın, Ameriean White.................... 4 & & & \\
\hline & Elm, English . & to 12 & & \\
\hline & 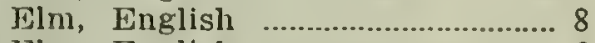 & to 10 & & 40 \\
\hline & 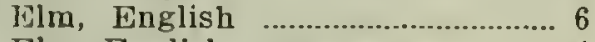 & to $\varepsilon$ & & \\
\hline & Eln, English ................................. 4 & to & & .20 \\
\hline & Elm, Huntingdon ……...................... 8 & & & \\
\hline & Elm, Huntingdon ...................... & to & & .3 \\
\hline & Locust, Pinl-Flowering ……….......10 & & & \\
\hline & Locust, Pink-Flowering …............ 8 & to & & 4 \\
\hline & Locust, Sen & & & \\
\hline & I.ocust, Sem & 1 & & \\
\hline & 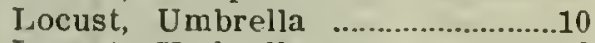 & to 1 & 2 & .4 \\
\hline & t. Umb & to 1 & & \\
\hline & Locust, Umbrella & to & & .2 \\
\hline & Flowering $\quad$..................6 6 & to & & \\
\hline & , Rose-Floweri & to & & .3 \\
\hline & rry, New Am & & & \\
\hline & erry, New Am & to 1 & $0 \mathrm{f}$ & \\
\hline & Mulberry, New Am & to & & \\
\hline & Mulberry, New American........... & to & & \\
\hline & Mulberry, Persian, or English.... 4 & to & & .3 \\
\hline & r, Balm of Gilead.... & & & \\
\hline & Poplar, Balm of Gilead..... & to 1 & & \\
\hline & , Balm of Gilead..... & & & \\
\hline & Lombardy ... & & &. \\
\hline & ardy $\quad \ldots . . . . . . . . . . .$. & to 1 & & \\
\hline & Poplar, Lombardy ........ & & & \\
\hline & Texas Umbrella .... & & & \\
\hline & s Umbrella & to & & .30 \\
\hline & 'Texas Umbrella & & & \\
\hline
\end{tabular}

\section{WEEPING DECIDUOUS TREES}

\begin{tabular}{|c|c|c|c|c|c|}
\hline Qua & Variety & & & & \\
\hline 5 & Ash, European Weeping. & $6 \mathrm{t}$ & & & \\
\hline 4 & Ash, Golden Weeping.... & $6 \mathrm{t}$ & & & \\
\hline 18 & Elm, Camperdown We & & & & \\
\hline 5 & Maple, Wier's Cut-Lea & & & & \\
\hline 60 & Mulberry, Tea's Weeping.. & $6 \mathrm{t}$ & & & \\
\hline & $\ldots$ & & & & \\
\hline
\end{tabular}

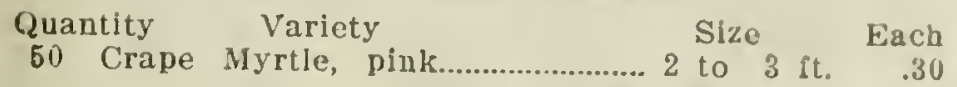

\section{EVERGREEN TREES AND SHRUBS}

The followıg list of syeclmen evergreen trees and plants is brouglit to attention from the fact that pur. chasers of nursery stock do not as a rule lilow that these fine specimen plants ean be secured any time from the Nursery, established in wooden tubs, boxes or eement pots and used for porch and office or store decoration.

These plants are specially selected for thls purpose flom the nulseries and are established in these containers. We also offer some of them "ballcd" whlch can be planted as specimens for lawns and parking trees any time during April and May. In order to dlspose of a quantity of this stock we are making special offering in prices as noted. If you want suggestions as to what you should order don't hesitate to write us.

WHEN TREES OR SHRUBS ESTABLISHED IN CEMENT POTS ARE DESIRED ADD TO QUOTATION ON BALLED PLANTS THE FOLLOWING PRICES:

$10 \frac{1}{2}$ inch cement pot

Each

$151 / 2$ inch cement pot.

$\$ 1.00$

$161 / 2$ inch cement pot.

1.50

$21 \frac{1}{2}$ inch cement pot.

2.00

\section{EVERGREEN TREES}

Quantity Variety

60 Acacia, Baileyana, potted......... 6 to $7 \mathrm{ft}$

100 Acacia, Melanoxylon, potted........6 6 to $7 \mathrm{ft}$.

20 Agave, Ameriean, balled............. 2 to $3 \mathrm{ft}$

3 Araucaria Bidwilli, in boxes....... 3 to $4 \mathrm{ft}$.

90 Arborvitae, American, in boxes, 12 to 18 in.

30 Arborvitae, Evergolden, balled. 4 to $5 \mathrm{ft}$.

5 Arborvitae, Evergolden, in boxes, 3 to $4 \mathrm{ft}$.

30 Arborvitae, Golden, balled........ 4 to $5 \mathrm{ft}$.

20 Arborvitae, Weeping, balled....... 4 to $5 \mathrm{ft}$.

5 Arborvitae, Weeping, in boxes... 4 to $5 \mathrm{ft}$.

10 Brachychiton, Diversifolia, bxs...12 to $15 \mathrm{ft}$.

30 California Big Tree, balled......... 3 to $4 \mathrm{ft}$.

3 Cedrus, Atlantica, in boxes......... 6 to $8 \mathrm{ft}$.

4 Cedrus, Atlantiea, in boxes......... \& to $5 \mathrm{ft}$.

200 Cedrus, Atlantica, balled.............. 4 to $5 \mathrm{ft}$.

70 Cedrus, Atlantica Glauca, balled 4 to $5 \mathrm{ft}$.

4 Cedrus, Deodara, tubs \& boxes, 10 to $12 \mathrm{ft}$.

20 Cedrus, Deodara, tubs \& boxes.. 8 to $10 \mathrm{ft}$

50 Cedrus, Deodara, tubs \& bores.. 6 to $8 \mathrm{ft}$.

10 Cedrus, Deodara, tubs \& boxes.. 4 to $5 \mathrm{ft}$.

15 Cedrus, Deodara, tubs \& boxes.. 3 to $4 \mathrm{ft}$.

25 Cedrus, Deodara, balled............ 4 to $5 \mathrm{ft}$.

25 Cedrus, Deodara, balled............... 3 to $4 \mathrm{ft}$.

140 Cedrus, Libani, balled.................... 4 to $5 \mathrm{ft}$.

5 Cephalotaxus, Fortunei, in tubs.. 5 to $6 \mathrm{ft}$.

30 Cypress, Arizonica, balled........... 4 to $5 \mathrm{ft}$.

150 Cypress, Funebris, balled............ 4 to $5 \mathrm{ft}$.

120 Cypress, Macrocarpa, balled......... 6 to $8 \mathrm{ft}$.

120 Cypress, Macrocarpa, balled........ 4 to $5 \mathrm{ft}$.

9 Cypress, Italian, in boxes........... 8 to $10 \mathrm{ft}$.

30 Cypress, Italian, in boxes............ 6 to $8 \mathrm{ft}$.

80 Cypress, Italian, 5 gal. cans....... 6 to $8 \mathrm{ft}$.

10 Cypress, Italian, 5 gal. cans........ 4 to $5 \mathrm{ft}$.
Each

.75

1.00

3.00

2.00

2.00

2.00

2.50

5.00

2.00

4.00

3.00

1.75

1.75

6.00

5.00

4.00

3.00

2.00

1.50

1.25

1.75

3.00

.60

.60

.75

.60

3.00

2.50

1.50

1.00
2.00 
Cypress, Italian, balled 6 to

$8 \mathrm{ft}$.

Cypress, Italian, balled

$5 \mathrm{ft} . \quad .75$

100

100

Cypress, Italian, balled

4 to

$4 \mathrm{ft}$.

.50

200

Eucalyptus, Leucoxylon ............. 3 to

$4 \mathrm{ft}$.

pots

$5 \mathrm{ft}$.

.25

300

600

130

Eucalyptus, Rudis, in pots...

6 to

$8 \mathrm{ft} . \quad .40$

$8 \mathrm{ft} . \quad .40$

Euctus, Tereticornis, pots.... 4 to

$5 \mathrm{ft}$.

Eiminalis, in pots.... 5 to

$6 \mathrm{ft}$.

.35

110

Eucalyptus, Meliodora, in pots.. 3 to

$4 \mathrm{ft}$.

.30

55

200

Eucalyptus, Resinifera, in pots.. 6 to

$4 \mathrm{ft}$.

.30

$7 \mathrm{ft} . \quad .40$

300

130

Grevillea, Robusta, in pots.......... 4 to

$5 \mathrm{ft}$.

.40

Jacara, Robusta, in pots..... 3 to $4 \mathrm{ft}$

.30

140

Juniperus, Japonis. 2 to $3 \mathrm{ft}$.

.30

1.00

Libocedrus, Decurrens, boxed, 10 to $12 \mathrm{in.} 6.00$

10 Libocedrus, Decurrens, tubs........ 6 to $8 \mathrm{ft}$.

3.50

Loquat Seedlings. balled............... 4 to

Loquat Seedlings, balled................. 3 to

5 ft. $\quad 1.00$

7 Magnolia, Grandiflora, tubs.......... 6 to

$4 \mathrm{ft} . \quad .75$

6 Magnolia, Grandiflora, tubs.......... 4 to

$8 \mathrm{ft} . \quad 4.00$

100

100

Magnolia, Grandiflora, balled...... 6 to

$6 \mathrm{ft} . \quad 3.00$

Magnolia, Grandiflora, balled...... 5 to

$8 \mathrm{ft}$.

2.00

$6 \mathrm{ft.} \quad 1.50$

100 Magnolia, Grandiflora, balled..... 4 to

$5 \mathrm{ft} . \quad 1.25$

Nolina, Parrii, balled..................... 2 to

$3 \mathrm{ft}$.

300

50

Pepper Trees, in pots.................... 4 to

$5 \mathrm{ft}$.

.75

.30

$5 \mathrm{ft.} \quad 1.00$

100 Pine, Halepensis, balled................... 6 to

$8 \mathrm{ft} . \quad 1.00$

200 Pine, Halepensis, balled.................. 4 to

150 Pine, Ponderosa, balled.................. 4 to

$5 \mathrm{ft} . \quad .75$

250 Pine, Radiata (Monterey, balled. 4 to

90 Pine, Sylvestris, balled............... 6 to

100 Pine, Sylvestris, balled.................. 4 to

$5 \mathrm{ft}$.

$5 \mathrm{ft}$.

$8 \mathrm{ft}$.

$5 \mathrm{ft}$.

Spruce, White, boxed .................... 3 to

$4 \mathrm{ft}$.

$4 \mathrm{ft}$.

Spruce, Pinsapo, balled................ 3 to

$4 \mathrm{ft}$.

Spruce, Pinsapo, boxed................. 3 to

Spruce, Pinsapo, boxed................. 2 to

$3 \mathrm{ft}$.

$4 \mathrm{ft}$.

$2 \mathrm{ft}$.

Yew Baccata, halled.

$11 / 2$ to

8 Yew, Irish Pyramidal, in tubs... 3 to $4 \mathrm{ft}$. 3.00

.75

.75

1.25

.75

3.00

2.50

3.00

2.50

3.00

.75

10 Yew, Variegated, Pyra., balled, 11/2 to

$2 \mathrm{ft}$.

1.00

\section{EVERGREEN SHRUBS}

Quantity Variety Size Each

6 Abelia, Grandiflora, in boxes...... 3 to $4 \mathrm{ft}$. 1.50

50 Abelia, Grandiflora, balled............ 4 to $5 \mathrm{ft}$. 1.25

5 Aucuba, Japonica, in tubs............1 1/2 to $2 \mathrm{ft}$. 1.00

100 Buxus, in variety, in tubs, $1 \frac{1 / 2}{2}$ to $2,75 \mathrm{c}$ to $\$ 1.50$ each

30 Choisya, Ternata, potted..........1/1/2 to $2 \mathrm{ft}$. .60

5 Choisya, Ternata, in boxes............ 2to $3 \mathrm{ft}$. 1.25

30 Datura, Arborea, potted..............11/2 to $2 \mathrm{ft} . \quad .50$

30 Elaeagnus, Reflexa, Pungens, bld, 3 to $4 \mathrm{ft}$. $\quad .60$

30 Elaeagnus, Reflexa Maculata, bld, 2 to $3 \mathrm{ft}$. $\quad .50$

30 Elaeagnus, Reflexa, Variegata, bld, 2 to $3 \mathrm{ft} . \quad .50$

50 Euonymus, Japonica, balled........ 2 to $3 \mathrm{ft}$. 50

50 Euonjmus, Jap. Albo-Mar, balled 3 to $4 \mathrm{ft} . \quad .60$

20 Euonymus, Jap. Albo-Mar., balled 2 to $3 \mathrm{ft}$. .50

14 Laurus, Nobilis, in boxes............ 3 to $4 \mathrm{ft}$. 1.50

15 Laurus, Nobilis, in pots............... 2 to $3 \mathrm{ft.} \quad .50$

20 Melaleuca. Ericifolia, in boxes.... 3 to $4 \mathrm{ft}$. 1.25

6 Nandina, Domestica, in tubs........ 2 to $3 \mathrm{ft} .1 .50$

20 Nandina, Domestica, balled......... 2 to $3 \mathrm{ft} . \quad .60$

20 Oleander, Lutea Plena, balled.... 2 to $3 \mathrm{ft}$. .50

15 Oleander, Album Plenum, balled, 2 to $3 \mathrm{ft}$. .50

10 Pittosporum, Tobira, balled........1 1/2 to $2 \mathrm{ft}$. .75 


\section{PALMS}

All tho fine, hurly varleties are offered herein that will bcautley the lawn, or they can be used for porch, pergola, when establlshed ln our new cement pots or in wooden tubs and boxcs.

WHEN PALMS IN CEMENT POTS ARE DESIRED -ADD TO QUOTATION ON BALLED STOCK THE FOLLOWING PRICES:

10 inch cement pot Each

$151 / 2$ inch cement pot....................................................... 1.25

$161 / 2$ inch cement pot......................................................... 1.50

$213 / 6$ inch cement pot................................................... 2.00

The prlces are so rcasonable that when such stock is desired and can be used to advantagc that all can purchase these plants.

Matched pairs can be supplied if so desired.

Quantity Varlety Size Each

10 Chamacrops, Excelsa, boxes....... 4 to $5 \mathrm{ft} .3 .00$

20 Chamaerops, Excelsa, boxes........ 3 to $4 \mathrm{ft}$. 2.00

10 Chamaerops, Excelsa, tubs.......... 2 to 3 ft. 1.50

80 Cliamaerops, Excelsa, balled....... 4 to 5 ft. 1.50

150 Chamarops, Excelsa, balled....... 3 to $4 \mathrm{ft} . \quad 1.00$

11 Chamaerops, Humilis, boxed...... 4 to 5 ft. 3.00

100 Chamaerops, Humilis, balled..... 3 to $4 \mathrm{ft}$. 1.00

10 Cocos, Australis, boxed................ 5 ft. $\quad \mathbf{7 . 5 0}$

10 Cocos, Australis, boxed................ $4 \mathrm{ft} . \quad 5.50$

10 Cocos, Australis, balled.................. 4 to $5 \mathrm{ft} .4 .00$

20 Cocos, Australis, balled............... 3 to $4 \mathrm{ft} . \quad 3.00$

20 Cycas, Revoluta, 12 in. wood tubs....\$3.50 to $\$ 7.00$ ea.

10 Erythea, Armata, in boxes......... 3 to $4 \mathrm{ft} .2 .50$

10 Erythea, Edulis, in boxes........... 2 to $3 \mathrm{ft} .2 .00$

20 Phoenix, Canariensis, in boxes... 4 to $5 \mathrm{ft}$. 4.00

20 Phoenix, Canariensis, in boxes.. 3 to $4 \mathrm{ft} . \quad 3.00$

50 Phoenix, Canariensis, balled....... 4 to $5 \mathrm{ft} . \quad 2.00$

30 Phoenix, Canariensis, balled....... 3 to $4 \mathrm{ft}$. 1.50

50 Phoenix Canariensis, balled........ 2 to $3 \mathrm{ft} . \quad 1.00$

30 Washington, Filifera, balled........ 4 to $5 \mathrm{ft}$. 1.50

50 Washington, Fillfera, balled........ 3 to $4 \mathrm{ft}$. 1.00

30 Washington, Filifera, balled........ 2 to $3 \mathrm{ft}$. .75

So Washington, Robusta, balled........ 3 to $4 \mathrm{ft} . \quad 1.00$

100 Washington, Robusta, balled....... 4 to $5 \mathrm{ft} . \quad 1.50$

50 Washington, Robusta, balled...... 2 to $3 \mathrm{ft}$. $\quad .75$

\section{GREENHOUSE STOCK}

Our assortment is complete in all kinds of greenhouse and conservatory plants. We call special attention to BOSTON FERNS established in tubs. They are magnificent plants.

25 Boston Ferus in 12 in. tubs; fine specimens, $\$ 3.50$ ea.

\section{TERMS}

Acceptance of orders sent us taken from this list are subject to the stock being unsold when the order is received.

Orders from unknown correspondents must be accompanied by remittance or satisfactory reference.

State distinctly when you want goods shipped-giving name of railroad station and the railroad over which the stock is to be forwarded.

Address all correspondence to FANCHER CREEK NURSERIES, Inc., P. O. Box 1310, Fresno, California. 
